\title{
Sociologia da Educação
}

\author{
Ana Maria F. Almeida \\ Heloísa Helena T. de Souza Martins
}

Interessar-se pela educação significa interessar-se pelos processos de inculcação e apropriação das habilidades, das sensibilidades e das disposiçôes apropriadas para uma determinada participação na sociedade. Supõe focalizar os processos de transmissão intergeracional, indagando sobre as condiçôes que tornam possível a permanência, ao longo do tempo, das hierarquias que dão sentido às interações entre os grupos em sociedades específicas.

As sociedades industrializadas contemporâneas têm de lidar com um elemento fundamental na equação da transmissão, a escola única e obrigatória, invenção coletiva que assumiu a forma que hoje conhecemos no século XIX, no bojo das transformações que acompanharam a criação dos Estados Nacionais e a construção da democracia moderna, forçando as famílias a dividirem com o Estado a responsabilidade e o trabalho de formação das novas gerações (Ariès, 1973; Ringer, 1979).

Encarregada de formar os cidadãos necessários à nova ordem política, a escola torna-se progressivamente encarregada também de garantir que o destino social dos indivíduos deixe de ser definido pelo nascimento. Estabelecida como um espaço à parte, controlando a definição de quem pode ser aluno tanto quanto a definição de quem pode ser professor, a escola se quer autônoma das famílias. Atribui-se, então, à máquina escolar de classificação a distribuição de diplomas e certificados que, pensados como resultado de um processo em que as crianças e jovens são avaliados em igualdade 
de condições, tomam legitimamente o lugar dos sobrenomes, isto é, dos nomes de família, na definição do percurso social a que estão destinados seus possuidores.

Desde a década de 1960, graças aos trabalhos de Pierre Bourdieu, Baudelot e Establet, Bowles e Gintis, Coleman, entre outros, sabemos que as coisas não se passam exatamente assim e que as operações escolares de separação e classificação dos alunos não estão imunes às lutas das famílias para garantir a transmissão dos seus patrimônios. A autonomia da escola para produzir seus veredictos é constantemente desafiada, carregando de sentido e conseqüências decisões que, apenas na aparência, podem ser pensadas exclusivamente por uma lógica pedagógica, como no caso da definição dos conteúdos curriculares legítimos, ou econômica, como no caso das decisões de se introduzir ou apoiar tal ou qual ramo do ensino, técnico ou generalista.

Essa é a questão que mobiliza os artigos reunidos neste Dossiê. O estudo dos percursos sociais dos filhos de imigrantes nos Estados Unidos realizado por Alejandro Portes e William Haller documenta exemplarmente essas lutas ao mobilizar a noção de "assimilação segmentada" para mostrar que os efeitos da ação escolar sobre os indivíduos só podem ser bem compreendidos quando examinados à luz da ação, anterior mas também concomitante, que o grupo social exerce sobre eles com mediação das famílias.

Os três artigos seguintes examinam essa questão com relação a grupos sociais específicos. No primeiro deles, Graziela Perosa focaliza as relações estreitas que unem famílias dos grupos médios e as escolas que escolhem para suas filhas, revelando o efeito dessas relações em termos de construção de possibilidades de profissionalização feminina na década de 1960. Operacionalizando a noção de "educação total", esse texto problematiza o significado da existência de um setor privado forte no interior do sistema de ensino brasileiro, mostrando como isso permitia às famílias encontrarem, num "mercado escolar", a modalidade de escolarização que mais serve aos seus interesses. Trata-se de uma situação que perdura e talvez tenha se acentuado hoje.

Kimi Tomizaki, por sua vez, a partir do seu estudo sobre os processos de transmissão intergeracional entre metalúrgicos de uma grande montadora, discute as transformações no sentido atribuído às qualificaçōes à medida que a expansão da escolarização se acentua, num contexto de estreitamento das oportunidades de trabalho, desvalorizando credenciais e impondo à própria escola, assim como às famílias, o confronto com o desacordo entre a promessa materializada no diploma e a realidade do mercado de trabalho. 
O texto de Elizabeth Linhares funciona, nesse contexto, como o outro lado do espelho, ao acompanhar as transformações vivenciadas por um grupo de antigos colonos do café hoje assentados na serra fluminense, mostrando como as possibilidades de relação que esse grupo pode estabelecer com a escola se modificam ao sabor das mudanças nas suas condições de existência e nas condiçôes institucionais de oferta escolar, implicando em alterações no ciclo de vida, nas formas de organização do tempo, nas modalidades de definição da dependência de uns para com os outros e, particularmente, de uma geração para com a outra.

Não poderíamos tratar desta questão sem um mergulho mais preciso na instituição escolar e em suas contradições tão bem captadas pelo artigo de Jean-Jacques Paul e Maria Lígia Barbosa, que estuda a contribuição dos professores para a redução das desigualdades sociais. Tendo como referência uma pesquisa comparativa realizada em Belo Horizonte (Brasil), Buenos Aires (Argentina), Santiago (Chile) e Leon-Guanahato (México), os autores discutem como o trabalho docente pode exercer papel significativo na melhoria da qualidade de ensino de alunos de diferentes origens sociais. A análise estatística dos dados revela a existência do que denominam "perversidade do efeito docente", ou seja, os professores nesses quatro países aparecem como fatores decisivos das trajetórias de seus alunos e acabam por reforçar as desigualdades sociais existentes.

Depois do mergulho na escola, uma imersão nas famílias é o que nos propõe o artigo escrito por Monique de Saint Martin, Mariana Heredia e Daniella Rocha. Nele, as autoras retomam a questão da correspondência entre condiçôes de vida e construção das percepções subjetivas sobre o mundo, incluindo aí as percepções sobre o lugar a ser ocupado nesse mundo pelas novas gerações que presidem os investimentos no futuro dos filhos. As autoras apontam, particularmente, a produtividade de se levar em conta o trabalho cotidiano desenvolvido coletivamente pelas famílias para construir sentidos precisos ao abundante e às vezes contraditório fluxo de experiências a que são expostas, usualmente pensadas de uma maneira totalizante como "experiências de classe".

Encerramos a discussão com um esforço de refletir sobre os próprios termos que a estruturam. Voltando aos processos de construção do sistema nacional de ensino, o artigo de Ana Maria F. Almeida procura pelas condições que permitiram a construção de uma relação causal entre educação e desigualdade de renda e sua elevação a uma posição proeminente no debate sobre os rumos da educação nacional nas últimas décadas, explicitando o 
papel aí desempenhado pelas disputas entre juristas e economistas pelo protagonismo na definição das competências de Estado e dispositivos de governo.

Apresentamos ao final uma entrevista com Christian Baudelot e Roger Establet, dois autores que mostram de maneira exemplar como a sociologia da educação ganha energia e sentido ao ser tomada como um capítulo dos estudos sobre as classes sociais e os processos de dominação. Indagando sobre as condições de produção da empresa intelectual compartilhada a que se dedicam desde os anos de 1960, procuramos explicitar a configuração particular que torna possível tal tratamento das questôes educacionais. $\mathrm{O}$ relato desses dois sociólogos nos permite perceber o contexto escolar e político dos anos de 1960, período em que realizam os seus estudos superiores, a militância política contra a guerra na Argélia e a compreensão da sociologia como um campo de reflexão sobre os acontecimentos que marcavam a sociedade francesa e a vida universitária. É interessante perceber, ainda, o processo de aprendizagem nas aulas de dois dos maiores intelectuais franceses, Bourdieu e Althusser, que tiveram importante papel na sua formação, com a ênfase no trabalho de pesquisa como condição para fazer e ensinar sociologia e no estabelecimento de uma ética intelectual.

Esperamos que esses breves comentários sobre os textos que compõem este Dossiê sobre a educação e a construção das desigualdades despertem o interesse dos leitores e que as reflexões aqui expostas motivem novas pesquisas.

\section{Referências Bibliográficas}

ARIÈs, Philippe. (1973), L'enfant et la vie familiale sous l'ancien régime. Paris, Seuil. RINGER, Fritz. (1979), Education and society in modern Europe. Bloomington, Indiana University Press. 